\title{
Standardizing the Scale to Measure the Attitude of the Homemakers towards the Management of Household Waste
}

\author{
Kalpana Srivastava, Nidhi Gupta
}

\begin{abstract}
Waste management has become one of the major issue universally. Inappropriate waste management could be a threat to environment as well as living beings too. Waste is not generated by any one entity but, industries, business and households are equally responsible for it. Proficient waste management starts from the source itself and for this it's very essential that individuals should have right attitude towards appropriate waste management. Management of household waste is very much related with the homemaker. The positive attitude of the homemaker can help in efficient waste management. The current research study was regarding standardizing the scale to measure the attitude of the homemakers towards the management of household waste. The scale consisted of two parts: (i) Segregation of household waste (ii) Disposal of household waste. Initially the scale consisted of 48 statements with the .80 reliability but after eliminating 6 indistinct statements the reliability of the attitude scale increased to .85 . So finally, the standardized scale to measure the attitude of the homemakers towards the management of household waste was constructed with 42 statements and .85 reliability.
\end{abstract}

Keywords: Waste management, Household, Attitude, Homemakers, Women.

\section{INTRODUCTION}

It is said that the most intelligent animal on this planet is man, but this intelligence of man has now created worries for mankind. Expansion of technologies, urbanization, intensifying standards of people and moreover, ravenousness of people has endangered the sustainability of the mankind and environment mutually. The development of trade and industry is increasing the waste like anything. In India, waste generation is expected to upsurge to an epic figure of 300 million by 2047 that means the per capita waste would upsurge from 500 grams in the present to 945 grams in future. Similarly with the growing waste the need of land for disposal of waste would also escalate. The rapid evolution of population could be directly linked with the heap of waste generated in the community. [1]

Revised Manuscript Received on November 15, 2019.

* Correspondence Author

Kalpana Srivastava*, Department of Family Resource Management, S.M.Patel College of Home Science, Sardar Patel University, Vallabh Vidyanagar, Gujarat, India. Email: kalpanaisha14@gmail.com

Nidhi Gupta, Department of Family Resource Management, S.M.Patel College of Home Science, Sardar Patel University, Vallabh Vidyanagar, Gujarat, India. Email: xyz2@blueeyesintlligence.org

(C) The Authors. Published by Blue Eyes Intelligence Engineering and Sciences Publication (BEIESP). This is an open access article under the CC BY-NC-ND license (http://creativecommons.org/licenses/by-nc-nd/4.0/)
Source segregation of household waste is the ultimate in efficient management of household waste but, all this is influenced by the attitude of the homemaker. The attitude is an individual belief regarding any person, object, custom or any matter. In psychology an attitude refers to a set of emotions, beliefs, and behaviors towards a particular object, person, thing, or an event. [8] The attitude of can be favorable/positive, neutral/indifferent. unfavorable/negative or

\section{REVIEW LITRETURE}

The study of Banga (2011) revealed that the attitude of forty percent respondents towards segregation were good while sixty percent believedthat its waste of time and dirty work. S. E. Kasala (2014) found that in Keko Machungwalacks, (Dar es Salaam, Africa), proper waste management and large number of residents (62\%) disposes solid waste into open drains and natural streams. This practice indicates that, the attitude of people towards waste management is not very encouraging and environment in Keko Machungwa is at risk

Kaithery NN et al. (2019) discovered that more than three-fourth of the respondents was positive towards waste management. The study conducted by Ahmadi Siroos (2018) found that the women were not segregating their household waste adequately and much of the waste that could have been recycled, were wasted.

The above studies revealed the not so very positive attitude of the women towards waste management and their immediate environment. This reflects the inclination of the women towards sustainable management of household waste and environment, which is an issue of distress.

The awareness and attitudes of the people towards waste can affect the entire solid waste management (SWM) system. All steps in SWM-from household waste storage to waste segregation, recycling, collection frequency, amount of littering, willingness to pay for services, and opposition to the treatment and disposal facilities - depends on the awareness and participation of people. Thus, awareness and attitudes are crucial in the success or failure of a SWM system. [2]

\section{RATIONALE OF THE STUDY}

The problem of waste management has been increasing globally day by day and the waste from the houses is one of the dynamic issue in the current scenario.

Published By:

Blue Eyes Intelligence Engineering

\& Sciences Publication

DOI: 10.35940/ijbsac.I0144.122919

Journal Website: www.ijbsac.org

(C) Copyright: All rights reserved. 
The role of women as homemakers is very pivotal, as the homemaker is the one who knows and decides better that when, what and how much item is required in the house. Homemakers are directly related to household chores whether it's developed, developing or under developed country. Women are born managers and always ready to take depends very much on the attitude of the person. It's very important that for efficient waste management the attitude of the homemakers should be positive. Once the attitude of the homemakers becomes positive then it becomes easy for them to handle their household waste competently. From the review it has been found that various research studies has been carried out related to attitude of the women towards managing their household waste but, most of the studies have not used standardized scale as a tool to measure the attitude. Therefore, to overcome these lacunae a need to develop a standardized scale was felt. The scale consisted of two main aspects:

(i) Segregation of household waste

(ii) Disposal of household waste.

\section{THE AIM OF THE PRESENT STUDY}

(1) Conduct a comprehensive review of literature in the field of related research area.

(2) Construct a list of statements based on facts and related researches on household waste.

(3) Standardize the scale for appraising the attitude of the homemakers regarding household waste management.

\section{METHODOLOGY}

A. Selection of Tool: A comprehensive review of literature was done to prepare an attitude scale on household waste management. The review of literature included various online and offline research studies, articles and magazines related to waste management and environment. A list of statements related to segregation of household waste and disposal of household waste was prepared that incorporated 48 statements in total. To measure, the attitude scale was constructed on the basis of five point Likert Scale. The complete scale consisted of 48 statements related to:

- Attitude regarding Segregation of household waste (14Statements).

- Attitude regarding Disposal of household waste (34 Statements).

B. Sample Selection: To check the reliability of the scale and each statement a pilot study was conducted on 45 homemakers of Vallabh Vidyanagar. Sample selection was done through stratified random sampling technique. The study area had 9 yards in total out of which 5 homemakers from each ward were randomly selected. The reliability of the scale was tested on 470 total respondents including those 45 respondents.

C. Scoring Of The Scale: Most frequently used Likert type scale in the study of social attitudes follow the pattern devised by Likert and for this reason it's known as Likert type scale. The scale consist of a number of statements which express either a favorable or unfavorable attitude towards the responsibilities but, the attainment and success of any goal

given item to which the respondent is asked to react. Usually five point of agreement or disagreement is used but many times three and seven points are also used. (7) In the current study the researcher had used 5 point rating scale of Likert to measure the attitude of the home makers towards household waste management. The five point scale consisted of "Strongly Disagree", "Disagree", "Unclear", "Agree", and "Strongly Agree". The scores assigned for the positive statement were one (1) to (5) i.e. Strongly Disagree was assigned one (1) and strongly agree was assigned five (5) respectively. In the negative statements it was reversed i.e. strongly disagree was assigned five (5) and strongly agree was given one (1) correspondingly.

The reliability of items on a Likert scale is something that cannot be overlooked since every researcher deems it necessary to collect accurate and objective data in conducting research. Hence, there is the need to estimate the reliability of the scale which is being used to measure the construct of interest. The reliability estimate for items on a Likert scale is measured using the reliability method known as Cronbach Alpha. Lee Cronbach in 1951 developed the Cronbach Alpha to offer a measure of the internal consistency of a scale or test, expressed as a number between 0and 1(Cronbach, 1951) which is used for items whose responses are on a scale. [8]

Seeing as Cronbach's alpha is the most common measure of internal consistency ("reliability"), it was selected to check the reliability of the given statements.

The formula used for Cronbach's alpha is:

$$
\alpha=\frac{N \cdot \bar{c}}{\bar{v}+(N-1) \cdot \bar{c}}
$$

Where:

$\mathrm{N}=$ the number of items.

$\overline{\mathrm{c}}=$ average covariance between item-pairs.

$\overline{\mathrm{v}}=$ average variance.

Cronbach's alpha is thus a function of the number of items in a test, the average covariance between pairs of items, and the variance of the total score.

\section{RESULT AND DISCUSSION}

The reliability was tested for overall attitude scale and the reliability came to 0.80 . Initially the attitude scale consisted of forty-eight statements but, after the test it had been found that Corrected Item-Total

Correlation for some statements were negative (-) and .0 value. This reflects that those selected items were entirely independent from one another i.e., are not correlated or share no covariance, the higher $\alpha$ coefficient, the more the items have shared covariance means the items were related to one another.

Blue Eyes Intelligence Engineering

\& Sciences Publication

DOI: 10.35940/ijbsac.I0144.122919

Journal Website: www.ijbsac.org

(C) Copyright: All rights reserved. 
Table: 1 List of eliminated items from the Attitude Scale

\begin{tabular}{|c|c|c|c|}
\hline S.No. & $\begin{array}{c}\text { Statement } \\
\text { No. }\end{array}$ & Statements & $\begin{array}{l}\text { Corrected } \\
\text { Item-Total } \\
\text { Correlation }\end{array}$ \\
\hline 1 & 6 & $\begin{array}{l}\text { I feel making } \\
\text { shopping list is not } \\
\text { possible every time. }\end{array}$ & -.200 \\
\hline 2 & 7 & $\begin{array}{l}\text { I think old paper / } \\
\text { magazines should } \\
\text { be sold out. }\end{array}$ & -.179 \\
\hline 3 & 12 & $\begin{array}{l}\text { I believe in using } \\
\text { disposables in a } \\
\text { gathering. }\end{array}$ & .033 \\
\hline 4 & 13 & $\begin{array}{ll}\text { I think old } & \text { old } \\
\text { toys/equipment } & \\
\text { should } & \text { be } \\
\text { discarded. } & \\
\end{array}$ & .056 \\
\hline 5 & 28 & $\begin{array}{l}\text { I think useless items } \\
\text { should be thrown in } \\
\text { waste. }\end{array}$ & -.363 \\
\hline 6 & 47 & $\begin{array}{lr}\text { I think } & \text { waste } \\
\text { segregation } & \text { does } \\
\text { not affect } & \text { human } \\
\text { health. } & \\
\end{array}$ & -.287 \\
\hline
\end{tabular}

Owning to this, excluding those items becomes necessary. Consequently, those items were removed, then again, the reliability of the scale was tested and then it had been discovered that reliability increases to 0.85 .

Table: 2 Final Reliability of the Attitude Scale

\begin{tabular}{|c|l|c|c|c|c|}
\hline \multicolumn{3}{|c|}{$\begin{array}{l}\text { Reliability } \\
\text { Statistics }\end{array}$} & \multicolumn{4}{|c|}{ Scale Statistics } \\
\hline $\begin{array}{l}\text { Cronbach } \\
\text { 's Alpha }\end{array}$ & $\begin{array}{l}\text { No. } \\
\text { of } \\
\text { Items }\end{array}$ & Mean & Variance & S. D. & $\begin{array}{l}\text { No. } \\
\text { of } \\
\text { Items }\end{array}$ \\
\hline .85 & 42 & 162.5 & 154.1 & 12.41 & 42 \\
\hline .80 & 48 & 174.9 & 139.9 & 11.83 & 48 \\
\hline
\end{tabular}

Earlier the scale consisted of 48 statements with .80 reliability but after eliminating 6 items from the complete scale finally consisted of 42 statements with .85 reliability (ref.table:2) where:

- Attitude regarding Segregation of household waste comprised of 13Statements.

- Attitude regarding Disposal of household waste comprised of 29 Statements.

According to the study of Keith (2017) the scale is reliable with the $(0.84-0.90)$ reliability.

\section{CONCLUSION}

The items declining the reliability, found indistinct and inapt were eliminated from the scale to increase the reliability of

Published By:

Blue Eyes Intelligence Engineering

\& Sciences Publication

(C) Copyright: All rights reserved. scale. Finally, with 0.85 reliability of the overall scale, the Standardized Scale to Measure the Attitude of the Homemakers towards the Management of Household Waste was successfully developed with 42 statements including Segregation and Disposal of Household Waste.

\section{REFERENCES}

1. Singh Jagbir \& Ramanathan AL. (2011) "Solid Waste ManagementPresent and Future Challenges", I.K. International Publishing House Pvt. Ltd., New Delhi \& Bangalore, ISBN No.978-93-80026-42-8

2. Zhu Da, Asnani P. U. , Zurbrügg Chris, Anapolsky Sebastian, Mani Shyamala (2008). "Improving Municipal Solid Waste Management in India: A Sourcebook for Policy Makers and Practitioners" www.tn.gov.in/cma/swm_in_india.pdf

3. Kaithery Nivya Noonhiyil \& Karunakaran Usha, (2019), "Study on attitude of household waste management in a rural area of Northern Kerala", International Journal of Community Medicine and Public Health, 2019 May; 6 (5):2095-2102, pISSN 2394-6032 | eISSN 2394-6040

4. Kasala, S.E. (2014) "Critical Analysis of the Challenges of Solid Waste Management Initiatives in Keko Machungwa Informal Settlement, Dar es Salaam". Journal of Environmental Protection, 5, 1064-1074.

5. Banga Margret (2011). "Household Knowledge, Attitudes and Practices in Solid Waste Segregation and Recycling: The Case of Urban Kampala". Zambia Social Science Journal, Vol. 2: No. 1, Article 4. Available at: http://scholarship.law.cornell.edu/zssj/vol2/iss1/4

6. Ahmadi Siroos (2018), "Effects of the Environmental Attitude and Responsibility on Household Waste Separation: Evidence from Iranian Married Women" The Open Psychology Journal, 2018, Volume 11, Pg.25-34

7. Kothari C.R., (2011), "RESEARCH METHODOLOGY: Methods and Techniques", New Age International Publishers, New Delhi-110002

8. Quansah Frank, (2017), "The Use of Cronbach Alpha Reliability Estimate In Research among Students in Public Universities in Ghana", Africa Journal of Teacher Education, ISSN 1916- 7822. A Journal of Spread Corporation, Vol. 6 No. 12017 Pages 56-64

9. Kendra Cherry Attitudes and Behavior in Psychology - Verywell Mind, August 01, 2019 https://www.verywellmind.com > attitudeshow-they-form-change-shape-behavior

10. Taber S. Keith, (2017), "The Use of Cronbach's Alpha When Developing and Reporting Research Instruments in Science Education", Research in Science Education https://doi.org/10.1007/s11165-016-9602-2

\section{AUTHORS PROFILE}

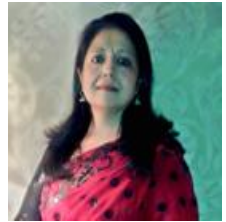

Kalpana Srivastava, is an Associate Professor in the Department of Family Resource Management at S.M.Patel College of Home Science, Sardar Patel University, Vallabh Vidyanagar, Dist. Anand, Gujarat-India. She has done her post-graduation and graduation from M.S.University of Baroda, Baroda, Gujarat. Has 23 years of teaching experience at under graduate and post graduate level. She has done a UGC project on Household Waste Management and many small research studies in the similar field. The subject of her doctoral is also Household Waste Management. There are number of research papers published to her credit in national and international journals. Moreover, she has contributed in number of reference books. The area of her interest is Resource Management, Environment, Hospitality Consumer Studies etc. She is fluent in Hindi, English and Gujarati as well. 


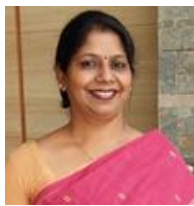

Nidhi Gupta, is working as an Associate Professor in the Department of Family Resource Management, S. M. Patel College of Home Science, Vallabh Vidyanagar, Gujarat. Her field of specialization is Consumers, Environment, Ergonomics. She has done her Ph.D in Home Management from M.S. University of Baroda with Senior Research Fellowship from ICAR (Indian Council of Agriculture Research) and M.Sc. in Family Resource Management from S. N. D. T. Women's University, Mumbai (Gold Medalist) and B.Sc. in Home Science from G. B. Pant University of Agriculture and Technology, Pantnagar (honors / Distinction). Total teaching experience (in years) at UG and PG level is 23 years. Three Ph.D students were awarded doctorate under her mentorship. She has taken up five Research Projects from various agencies including Ministry of Health and Family Welfare, Government of India and UGC New Delhi. She has been the guest faculty /subject expert in number of institutes like Kidney hospital, Nadiad Extension Education Institute, Ministry of Agriculture, Knowledge Consortium of Gujarat and SANDHAN (live television lecture series from BISAG), Gandhinagar and published number of reference books and research papers with international/ National publishers of repute and chaired /organized number of conferences and workshops on various current issues.

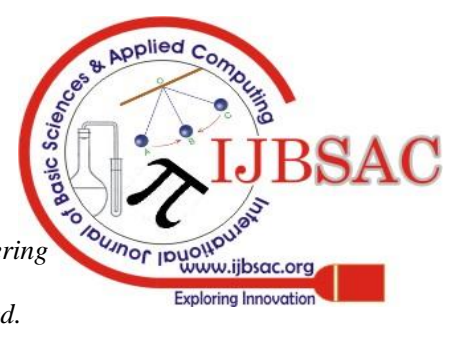

